\title{
Burton Church, Sussex
}

\section{J. L. André}

To cite this article: J. L. André (1890) Burton Church, Sussex, Archaeological Journal, 47:1, 89-100, DOI: $10.1080 / 00665983.1890 .10852413$

To link to this article: http://dx.doi.org/10.1080/00665983.1890.10852413

曲 Published online: 15 Jul 2014.

Submit your article to this journal 준

Q View related articles ¿ 


\section{Arefaedogical $\mathfrak{3}$ ontmal.}

\section{JUNE, 1890. \\ BURTON CHURCH, SUSSEX.1}

By J. L. ANDRÉ.

The parish of Burton, in Sussex, is chiefly included in the park attached to the manor house, and is so thinly populated that in 1821 it contained only one house-the mansion, and fourteen inhabitants. Since then the population has much increased, though still, I believe, under one hundred souls, and of the thirty parishes in England bearing the name of Burton, there is only one with fewer inhabitants, that of West Burton, Notts. As in a few other Sussex parishes there are some detached portions, one of which is as far off as South Bersted, and part of the land belonged to the nunnery of Godstow, in Oxfordshire.

In Domesday Book the parish is designated Botechitone, and it is curious to observe that it is spelt in precisely the same way in the will of John Goring, which was made shortly before his death, in 1521 . In the eleventh century document mention is made of one mill, which is no doubt identical, as to site, with the present water mill, and the extensive and beautiful fishponds are also stated as then existing. ${ }^{2}$ Besides the ancient use of the water power in connection with the mill, it was likewise applied afterwards to aid the iron

\footnotetext{
${ }^{1}$ Read at the Monthly Meeting of the Institute January 9th, 1890 .

2 The following is the account of Burton as recorded in Domesday Book. "Robertus tenet de comite BotECHITone et Hamelinus de eo. Ulmer | tenuit de rege E. pro ijbus Maneriis in alodium Tunc et modo se defendebat pro $\vec{V}$ hidis | Terra est V carucarum. In domiVOL, XIVII (No. 186)
}

nio sunt $\mathrm{ij}^{\mathrm{x}}$ et viij villani et iij bordarii cum ij | carucis Ibi ij servi et $\mathbf{j}$ molinus de $x j$ solidis. Piscaria de cetis $^{\text {tis }}$ lxxxoctoginta $i$ et iiij acræ prati et silva ij porcorum T.R.E. et post valuit xl solidos, Modo c solidos." Domesdny Book in relation to the County of sussex. p. 64 . 
industry, once so extensive in Sussex, as there is a record of the existence of a "fforge or iron mill," at Burton, near Petworth, in 1653.

The manor has descended from the Dawtreys, who appear to be the earliest known possessors, successively to the families of St. John, Dyke, Goring, and Biddulph, each of the changes of ownership having been made by marriages with heiresses. By the marriage of Eva Dawtrey, who died in 1354 , the estate passed to Sir Edward St. John, whose daughter Elizabeth, similarly carried it to Henry Dyke; and his daughter Constantia, by her union with John Goring, of Burton, conveyed it to the Gorings, in whose possession it continued for more than two centuries, finally becoming the property of the Biddulphs by the marriage of Ann Goring with Richard Biddulph, of Staflordshire.

The manor house, standing in the midst of the beautiful well-wooded park, was re-built in the reign of Elizabeth, probably late in the sixteenth century, as the architecture of the structure appears to have been the rich semi-classic style, of which there were so many examples in Sussex, as at Bolnbrook, Brambletye, Slaugham, and elsewhere. Horsfield gives an engraving of the principal entrance, which comprised a rather insignificant doorway, over which was a rich panel with the Goring arms, crest, and mantling, and a three light window; both were flanked by pilasters with elaborate corbels and bases, the whole being crowned by a decorative frieze. ${ }^{2}$ The Elizabethan erection was destroyed by fire about the year 1756 , when it appears " many valuable portraits of the Goring family by the early masters" were destroyed." The house was again re-built with much splendour by Richard Biddulph, but in its turn was ruined in the same manner, and finally re-erected in 1826. The present building is a plain unadorned structure, but is said to contain a brass staircase, brought from another Sussex mansion, the grand dwelling at Michelgrove, when it was pulled down in 1826.

From Mr. Hussey's Churches of Kent, Sussex, and Surrey, we learn that although no church or chapel is mentioned in Domesday Book, as existing at Burton, the

1 Sce Sussex Archreological Collections, vol, xviii, p. 16.
: Horsfield, vol. ii, p. 172.

3 Dallawny, Arundel Rape, vol. ii, 283. 
name occurs in the record of the Taxation of Pope Nicholas IV, in 1291, showing that there was an ecclesiastical building at that date, and there is also mention of such an edifice in the Nonx Roll compiled about 1341 in the reign of Edward III. ${ }^{1}$ The benefice was consolidated with that of Coates, an adjoining parish, in 1520, during the episcopate of Bishop Sherburn, of Chichester. ${ }^{2}$ The church was partly rebuilt and repaired by an injunction from Archbishop Juxon in 1636. Horsfield, whose History of Sussex, was issued in 1835 , states that no service had then been performed for many years, and Hussey, whose book was published in 1852 makes the same statement, which, however; will not apply at the present time, but the edifice, standing as it does completely buried in trees, was so little known in the early part of this century as to give rise to a Sussex joke, that, no one knew there was a church at Burton till the hounds of a hunting party stumbled upon it. Tree-bordered churchyards are not common in Sussex, though numerous instances may be met with in Essex. Such trees were not only planted for ornament, but for use, and there was " an act passed temp. Edward I, 1307 (entitled " $\mathrm{Ne}$ rector prosternat arbores in cemeterio") which decrees that such trees were church property, and do not belong to the parishioners, but are under the priest's care, and the act further says, "and yet seeing these trees are often planted to defend the force of the wind from hurting of the church, they are only to be felled when the church requires needful reparations when they may be used for such a purpose to help the parishioners but are not ordered to be so."3 The churchyard is now of very limited extent and contains only one or two graves on the south side. The dedication of the church is unknown, and the one bell bears no inscription. The edifice comprises a nave measuring internally $26 \mathrm{ft}$. by $14 \mathrm{ft}$. $6 \mathrm{in}$., and a chancel $13 \mathrm{ft} .8 \mathrm{in}$. by $11 \mathrm{ft} .8 \mathrm{in}$. These dimensions show how small the entire building is. Over the west end is erected a short stone-capped bell-turret carried on a circular seventeenth century arch; there are plain hollow chamfered west and south doorways, and the

1 See Hussey, p. 210.

2 Dallaway, p. 284.
"Mr. Robertson Blaine, in "Athe. næum," No. 1963, June 10, 1865. 
windows are all more or less mutilated Third-Pointed ones of two lights each. The interior is equally unattractive as regards the structural features: there is no chancel arch, and the nave roof is a plain king-post one ceiled between the principals, whilst that of the chancel is modern. The font a tub-shaped mass, has a simple roll round the upper edge, and as it shows traces of the staples by which the lid was fastened, is probably of Norman date. There is a very small and perfectly plain piscina in the chancel, and some good linen-fold panels, worked up into more recent open seats, remain in the nave. The Canon of 1603 , ordering that every church should have a pulpit has been disregarded at Burton, as it possesses none whatever. ${ }^{1}$ All these details offer but little that is attractive to the antiquary, but there are three features which redeem Burton from being a most common-place parish church, these are the rood screen and loft, a fragment of wall-painting, and the sepulchral monuments.

Chancel-screens are held to be somewhat rare in Sussex, though there are many excellent examples, including decorated ones at S. Mary's Hospital, Chichester, and Etchingham, whilst the whole of the chancel parcloses at Eastbourne are of that period. There is also a fine perpendicular screen now hidden in the belfry at Ardingly. The example at Burton is a simple Third l'ointed one, of late fifteenth century date, with plain fenestrations of five-foiled openings supermullioned. Still it is an interesting example as it retains its original polychromatic decorations, and very little painted woodwork is to be met with in this part of England; the only other Sussex specimen of painting on screen work that I have found being at Thakeham, where the panels had

1 In Bishop Ridley's Visitation Articles for the Diocese of London, in 1550 , one of the enquiries is "Whether your church be kept in due and lawful reparation, and whether there be a comely pulpit set up in the same" ; and S. Charles Borromeo, who died in 1584 , in his "Instructions on Ecclesiastical Building," drawn up for the Church of Milan, says that in every parochial church "where an awbo cannot be erected for the recital of the Gospel, or for religious preaching, a pulpit constructed altogether of wooden boards (which should be strong and of proper work and form) should be erected on the Gospel side as before (i.e. in the case where an ambo was practicable) and serve for the purpose of reading the Gospel and of religious preaching." p. 90. ed. Dolman, 1857. These extracts show that even before the seventeenth century, the pulpit was considered a necessary fitting in many churches, not only in England but on the Continent. 
a powdering of roses. Doubtless the Sussex screens once glowed with gilding and colours, as was the case at Brighton, and at Horsham, where the rood-screen remained till 1826. Brighton still has the loft over the screen, and there is a modern restoration of one at Fletching. Both of these have the gallery carried on fan-groining, but at Burton the construction is the same as that shown at Sherringham, Norfolk, the floor in each case being supported equally by the cornice of the screen, and by a girder at some distance to the west of it; the latter beam having curved and spandrelled braces at the ends, though at Burton only one of these remains, that on the north side. ${ }^{1}$ Rood-lofts, constructed as at Burton and Sherringham, appear to be much less numerous than those where the gallery is erected over fan-groining, the reason probably being that when the roods and lofts, but not the screens, were ordered to be destroyed at the Reformation, the destruction of a groined rood-loft would have involved the demolition of the entire upper part of the enclosure itself; whilst in the other case the floor and its wooden supports could be removed without necessitating the mutilation of the screen.

In the north wall of the nave has been a square-headed Third Pointed window, of which the double chamfered jambs and moulded labels remain, though the tracery has gone, there being now only a plain upright mullion, dividing the window-way into two lights. Inside, on the east splay of the window recess, is a remarkable example of painted work; it has faded very much, but still shows clearly a female figure, tied head-downwards to a saltire cross ragulee, a mass of deep red hair hangs from the head, and the countenance is that of a round-faced young woman. Some lines of colour and other portions of the design are too indistinct for identification. The absence of a nimbus from the effigy might be considered to imply that no saintly martydom was here intended to be represented and I am unaware of any record of the death of a female saint by this singular method of crucifixion. Yet that the effigy is of a martyr seems certain from the letter $\mathrm{S}$. below the figure followed by another capital and other

\footnotetext{
1 A piece of battlemented coraicework now fixed to the west end of the

church, may have been part of the rood-heam.
} 
characters too faded to be deciphered, but evidently the name of the female depicted. ${ }^{1}$ There is no mention of this very remarkable picture in the S. Kensington List of Buildings, \&c., nor have I met with any notice of it elsewhere. Below the figure is a band of diaper work much resembling the so-called "box pattern," which was a great favourite for patchwork, and Berlin wool embroidery some forty years ago.

At the time of the repairs in 1636 the walls of the nave were decorated with several texts in ornamental borders, and at the same date a large and elaborate representation of the Royal Arms was placed over the south doorway; it bears the words "Christo auspice regno" beneath the scutcheon; a motto which appears frequently on the coins of Charles I.

In the south wall of the chancel is a recessed and canopied tomb of fifteenth century date, the opening having a four-centred arch over which is an ogee canopy enclosing a plain shield; the label is somewhat coarsely crocketted and finialled, but there are flanking pinnacles of better execution. The arch is only $3 \mathrm{ft}$. $11 \mathrm{in}$. wide, and covers the mutilated effigy of a lady, who wears a kind of mitred head-dress, the liripipe, or tippet of which is seen folded up on the cushion supporting the head of the figure. The gown is open in front and has wide lappets at the neck, whilst at the lady's feet has been the representation of a dog. The staiuette is only $3 \mathrm{ft}$. 6 in. in length and 11 in. in width and I conjecture that the smallness of the tomb and its effigy was occasioned by the

1 A rough analysis of the "passions" of the female martyr saints recorded in Alban Butler's "Lives," furnishes the following results; though in many cases the tortures endured by the martyrs were so numerous and lingering, that it is difficult to fix upon the precise cause of death.

Brimadrid. - S. S. Agnes, Basilisa, Cantinilla, Catharine, Cecilia, Crispina, Denysa, Faith, Felicitas, Flora and Mary, Januana, Juliana, Justina, Margaret (of Antioch), Manila aud Alodia, Osyth, Regina and her companions Rufina and Secunda, Soteris, Theodora, and Winifride.

BurnT Alive.-S. S. Agape and companions, Afra and Digna, Anastania, Domitilla, Eunonia, Eutropia, Eulalia,
Euphronia, Flavia, Julitta, Theo, and Valentina ; S. Victoria was suspended orer a fire.

CRUCIFIED. - On the rack, \&c. S. S. Eulalia (of Barcelona), and Julia; torn on rack, Justa and Theodosia; ; torn with hooks S. Engratis.

Drowned-S. S. Martha (of Persia), Symphorosa, Theodora and companions; S. Potansiana smothered in a cauldron of melted pitch.

STABBED.-S. S. Anysia and Victoria. STCNED.-S. Theodota.

Strangled. - S. S. Beatrice, and Rufina. TORN BY BEASTS. - S. S. Blandina, Marciana, Thecla.

WhIIPED To DEstH. S. Bibiana. 
diminutive size of the chancel in which they are placed. Sussex is somewhat remarkable for its small sepulchral memorials, there is the well-known cross-legged effigy of a knight at Horstead Keynes, and at Fletching is a singular cross slab only $2 \mathrm{ft}$. 6 in. long by $7 \frac{1}{2} \mathrm{in}$. in its widest part, whilst at Cocking, not far from Burton, is a recessed tomb of nearly the same size as at the latter place; it has an ogee shaped, and trefoiled arch with label and finial, it has also had side pinnacles as in the Burton example, but only one of which remains.

In the south wall of the nave is another recessed monument, it is of late Perpendicular work, and has a flat canopy over a plain high tomb; the inscription has perished, but at the back of the recess remains the kneeling figure of a man in piate armour, from which proceeds a label inscribed "Delicta juventut $(i s)$ mee et ignorancias meas ne memineris dne." Four scutcheons of arms remain at the angles of the slab and the monument is that of John Goring, who died in 1521, and by his will directed that a tomb should be made for him with the sentence from the Psalms which $\mathrm{I}$ have just quoted, written upon it. He bequeathed to the priory of Hardham, a religious house in the neighbourhood, 40s. for sixty masses and solemn dirge, and he directed his "evidences" to be kept in that priory until his son, then a minor, should come of age. He left $40 \mathrm{~s}$. to the prior of Durford, likewise a religious house in the vicinity of Burton, and to the monastery of Sion 60s. To the church at Botechitone he bequeathed a chalice worth $26 \mathrm{~s}$, a banner cloth of $10 \mathrm{~s}$. value, and two kine to maintain a light before the rood. To his four daughters a legacy of $£ 400$. John Goring, the above testator, by his marriage with Constantia Dyke, brought the manor of Burton into the possession of the Gorings, as previously mentioned.

Opposite the last described tomb is another, which projects into the nave; it has a canopy of rich but debased character, and designed in the half-Classic, half-Gothic style, of which Sussex has so many examples, the most elaborate one, probably, being the chantry of the De La Warr's at Boxgrove. At the back of the monument have been kneeling figures of a knight and lady, both of whom were habited in tabards; the male effigy has gone, but 
fortunately the other remains, and is probably unique amongst our English brasses, as it shows a female in an armorial garment belonging to the male sex, instead of being habited in the usual heraldic mantle. Besides the arms on the lady's tabard there are four shields displaying those of the Gorings and their family alliances, all of which retain their colours in a well preserved state. Various small effigies now lost, and several inscriptions, fill in the rest of the slab at the back of the tomb, and, from the irregular manner in which they occur, it is probable that they are not in their original places. At the risk of being somewhat tedious I propose to quote these writings, and then enter upon a few remarks upon each, on the persons mentioned therein, and on some of their descendants.

Immediately above a central shield and the effigy of the lady are two plates of unequal size, on the largest of which is written-

0 God forget my Synnes Impute

them not to me but forgeue me for thy

dere sone Jesus Christe sake \& Judge

me accordinge vnto thy Inscrutable

mercy for yf we saye $y t$ we have no synne

we deceaue $o^{r}$ selves and theris no truth in vs.

In a line with this is another plate, inscribed-

I have Geven deligent care vnto the and nowe I see the wyth inyn eyes Wherfor I geue myne owne selfe the blame; and talke Repentance in the duste and Ashes.

Under the missing figure of the kneeling knight there was, till within a few years since, the following, which has now disappeared :-

Syr Wyllin Gorynge Knight one of $y^{\mathrm{e}}$ Gen

tlmen of $\mathrm{y}^{\mathrm{e}}$ preuie chamber to kyng Edward

the Syxte deceassed the xviii daye of March

$\mathrm{An}^{\circ} 1553$ and lyeth here Intombed

Beneath the lady is a plate bearing these words-

Elizabeth goringe wife of $\mathrm{y}^{\mathrm{e}}$ same $\mathrm{S}^{\mathrm{r}}$ Willim

$\&$ daught of John Couert of Slaugham dyed $y^{\mathbf{e}}$

xvi. of Novebe 1558 and lyeth here itombed.

Another plate bears the following-

Henry Goringe sonne \& heyre of $\mathrm{y}^{\mathrm{e}}$ same $\mathrm{S}^{\mathrm{r}}$

Willim \& Elisabeth nowe lyuing \& maried to dorethe one of $y^{\theta}$ daught \& heyres of Willim Everad Esquire dyed \& hath Issue by her lyuing Willim Edward : barbare \& Elizabeth. 
Beneath the epitaph to Dame Goring is a plate withAnne delalind daughter of $\mathbf{y}^{e}$ same syr Willim \& Elizabeth late the wyfe of syr George delalind of $\mathrm{y}^{\mathrm{c}}$ Contye of dorset and nowe wife to Fraune ${ }^{e s}$ browne Esquir brother to $\mathrm{y}^{\ominus}$ Viscount Montague.

A plate placed perpendicularly is inscribed-

Robert Goringe deceassed one other soñe of $\mathrm{Sy}^{\mathrm{r}}$ Willim and Elizabeth latly maried to mary daughter of Thomas Onley Esquire ha vynge Issue by her now lyving Elizabeth.

And lastly there is an inscription as follows-

Thomas Edward \& Custance: childre of the same: Willim \& Elizabeth depted in ther infancy \& one other dyed afore it had Receved christedom.

The two religious inscriptions, written at a time when the Reformation was in progress, but the result as yet uncertain, would suggest from the Scriptural phraseology employed, that they were placed upon the tomb to ensure its respect by either of the two contending parties, the Protestant or the Catholic, as the sentiments conveyed in them would not offend the opinions of either body.

The Sir William Goring commemorated in the inscription now missing, was the son and heir of John Goring, whose monument has just been described. At the dissolution of the monasteries the lands at Burton held by Godstow Nunnery were given to him, and likewise the landed property belonging to Hardham Priory "as heir to the founder." " The Dawtreys are believed to have founded the house at Hardham, and to which their successors at Burton, the St. Johns and Gorings, were considerable benefactors.

1 The expression "take Repentance," for becoming penitent, was a sixteenth century phrase, thus Fibian tells us that Clulperic on one occasion "toke great repentance," Fabian's Chronicle, p. 89., ed. Ellis, 1811.

2 Sir William Goring was "heir to the founder ". of Hardham Priory from having inherited the estates of Sir William Dawtrey, who made the foundation of that monastery in the reign of Henry II. A good instance of the practice of considering the successors of a founder as entitled to all the honour due to the original benefactor, is shown iu the following extract from a document bearing date 1533 , and to which the Abbot and his brethren at Easby Abbey, Yorkshire, put their common seal. It VOL. XIVII

states that Abbot Robert, " received the day of the making hereof: Rt. Hon. John Lord Scrope of Bolton as our veray truee and undoubted founder of our said Monasterye, with procession and all other solemn priuitie and ceremonie as doth apperteyne and belong thereunto, according as ourpredecessors have heretofore at all times receyvede his noble ancestoyors as founders of the sayme." The document proceeds to say that Lord Scrope was entitled to the share in then prayers and good works, which "appenteyne and belonge unto the just title and right of a founder and as haith bene accustomede and done by our predecessours unto his auncestors our founders heretofore." Quoted in Ass. Arch. Soc., Rep. vol. ii (1852-1853), p. 326. 
Henry Goring, recorded in the next inscription as son and heir of Sir William, was born in 1521, and died 15th December, 1594. He was high sheriff in the reign of Elizabeth, and in 1577 , when that monarch contemplated visits to the country seats of Lord Montague, Lord Buckhurst, and Lord Arundel, she proposed to honour Mr. Henry Goring at Burton with a short stay at his house. The project was stopped by the plague, ${ }^{1}$ and its abandonment was probably little regretted by Henry Goring, as he wrote a letter on the 7 th of July, in the above year, to Sir William More, of Loseley, near Godalming, Surrey, as an old friend, and "hearing that the Queen has laid two nights at his house in Sussex," he asks how he is to entertain her, and "whether she brings her own stuff, beer, and other provisions or whether Sir William provided every part." Henry Goring contributed one hundred pounds towards the fund raised in aid of the opposition to the Spanish Armada, ${ }^{3}$ and in the hands of his descendants Burton continued till it passed to the Biddulphs, as before mentioned; from him are also descended the Gorings of Wiston, who still own that manor. The inscription states that he married Dorothy, daughter of William Everard; his brother George, of whom I shall now sperk, wedded Mary the eldest daughter of the same gentleman.

George, the second son of Sir William Goring, is not noticed in any of the inscriptions remaining, but he was destined to be the progenitor of two men who played important parts in the days of Charles I. This George Goring bore a son of the same name, who likewise had a son George, whom Charles created Lord Goring of Hurstpierpoint, in 1626, and afterwards Earl of Norwich. He appears to have been in the main a staunch Royalist, and the records of his daring and fortitude are such matters of history that no more need be said here respecting him, except to note the fact that by his precipitate action at Portsmouth, he caused the outbreak of the Civil war. He died in 1662.

The eldest son of the above-mentioned Earl of Norwich

1 S. A. C., V. p. 192.

2 S. A. C., V. p. 193.

3 List of "Names of nobility and gentry who contributed to the defence of this country at the time of the Spanish Invasion in 1538." Quoted S. A. C. I., 32. 
was named George, the fourth in direct succession. Like his father, he was a zealous supporter of Charles I, and resembled his sire in bravery, but was rash, unscrupulous, and dissolute. After a turbulent existence he died in the lifetime of his father, leaving no issue, and the earldom of Norwich, on the decease of the latter, passed to his son Charles, who died childless and the title became extinct."

Robert Goringe, "one other sone of Syr William," is stated in the inscription to have married a daughter of Thomas Onley, or Olney, Esq., and it is, perhaps, worth noting that the families of Goring and Onley have representatives in Sussex at the present day. ${ }^{2}$

The last writing on the tomb states that one other child " died afore it had Receved christedom," which is an unusual piece of information. Inscriptions in memory of chrysom children are fairly numerous, but hitherto I have not met with one recording that a child died without baptism. ${ }^{3}$

The Gorings originally came from the place of the same designation on the coast of Sussex, and the name occurs for the first time in a list of sheriffs in the reign of Edward IV. The patronymic has been spelt Goring, Goringe, or Gorringe ; and the arms of the family, a red chevron and three annulets, or rings, on a white field, are said to contain a pun on the word Go-ring ; the crest is a lion rampant regardant.

The house of Stuart was powerfully supported by many of the Sussex gentry, conspicuously so by the Ashburnhams, Carylls, Gages, and Gorings, though the fidelity of some members of the last-named family was occasionally of rather a doubtful character. A Sir William Goring of Burton was among the prisoners taken by Sir William

1 A portrait of George Lord Goring, from a picture by Vandylse, is given in "Lodge's Portraits," it is 'accom. panied by a Memoir in which the Author states that, "almost all writers who have mentioned either" - the Earl of Norwich, or his son George, have been betrayed "into error and confusion." "These Mistakes were," he continues, "perhaps easy, Both bore the same names and title, flourished at the same time and in similar characters; both were courtiers, wits, warriors, and loyalists. It was in morals only that they differed and the disadvantage lay on the side of the son." Lodge's Portraits vol. iv. p.p. 313. 314 .

2 See Standard Jan. 14th, 1890. Law Report.

3 To "receive Christendom," was a sixteenth century variation of "being christened." Fabian for instance tells us that Augustine required of the Welsh Bishops that they should "geue christendome to the children in $y^{\circ}$ manner $\mathrm{y}^{\mathrm{t}}$ is vsed in $\mathrm{y}^{\theta}$ chyrche of Rome." Chronicle, p. 96, ed. Ellis. 
Waller at the siege of Arundel Castle in 1644, and also "Ensign Goringe, and gentleman Henry Goringe" " Colonel George Goring is mentioned in the catalogue of Royalist Compositions, published in 1655 , as having compounded for his estates for a sum of $£ 400$, Henry Goring of Burton, Gentleman, for $£ 250$, and Henry Goring of Sullington for $£ 40,{ }^{2}$ After the Restoration of Charles II the name of Henry Goringe occurs amongst those of the Sussex gentlemen intended to be knights of the proposed order of the Royal Oak, projected by that King, and he is stated therein to have had an estate of $£ 2,000$ per annum. Long after the second downfall of the Stuarts the Gorings were suspected of being their partisans, for in the diary of Thomas Marchant, published in the Vol. xxv of the Sussex Archoological Collections, it is recorded under the date of June 26th, 1715, that "About this time there was a great talk that the Duke of Ormond, the great supporter of the Chevalier St. George, commonly. called the Pretender, went off at Shoreham with Sir Henry Goring, Mr. Middleton, and one or two others." The Sir Henry Goring here mentioned was one of the Wiston branch of the family; he died in 1752, and was buried at Billingshurst, in Sussex, where he has a tomb inside the church, and where many members of the Goring family are interred.

A ledger in the chancel at Burton commemorates Sir William Goring, who died on February 29th, 1723, in his 65 th year, and appears to have been the last of the Gorings buried in this church.

The Burrell MSS. mention an inscription in memory of Mary Goring, "the most deservedly beloved wife" of Sir Henry Goring, Bart., who died September 12th 1694; and also one for Ann Biddulph, "the most deservedly beloved wife" of Richard Biddulph, who changed this life for a better on 25th of October, 1679, ætatis 27. Requiescat in Pace." 3

Probably a more unpretending little edifice than Burton Church does not exist, but I think that the internal features here described, the sepulchral monuments, and the associations connected with them, redeem it from being altogether devoid of interest, and that such interest is more than local.

I S. A. C., ix. 53, and V. 63 note.

S. A. C., xix. 94 .

- Burrell, Add. MSS. 5699 . 